\title{
Erratum to: Therapeutic characteristics of Galician mineral and thermal waters (NW-Spain) ascribed to their local/regional geological setting
}

\author{
Ricardo Juncosa Rivera ${ }^{1} \cdot$ Rosa Meijide Failde ${ }^{1} \cdot$ Jorge Delgado Martin $^{1}$
}

Published online: 27 April 2017

(C) Springer International Publishing Switzerland 2017

\section{Erratum to: Sustain Water Resour Manag}

DOI 10.1007/s40899-017-0112-9

In the original publication of the article, the name of Jorge Delgado Martin has been published incorrectly. The error in the author's name is now corrected.

The online version of the original article can be found under doi:10.1007/s40899-017-0112-9.

\section{Ricardo Juncosa Rivera}

rjuncosa@udc.es

1 School of Civil Engineering, University of A Coruña, Campus de Elviña s/n., 15192 A Coruña, Spain 